KS. JAN KUDELKA

\title{
ZA OJCZYZNĘ I KOŚCIÓL - KS. JÓZEF BARDEL
}

Liczba ofiar, które oddały życie za Ojczyznę i Kościól, wciąż nie jest dokładnie ustalona. Do takich postaci - nieznanych a godnych pamięci - należy również syn Ziemi Bocheńskiej, ks. Józef Bardel, który zginął rozstrzelany z wieloma zakładnikami 21 sierpnia 1941 roku, w dzielnicy Nowego Sącza - Biegonicach.

\section{ŚRODOWISKO RODZINNE}

Mikluszowice, rodzinna wieś ks. Józefa Bardla, są położone w Małopolsce, nad rzeką Rabą. Miejscowość jest oddalona 10 kilometrów od Bochni w kierunku północnym. Na przestrzeni wieków nazwa wioski przybierała różne formy. $\mathrm{Na}$ zmiany te miała wpływ różna pisownia, co w głównej mierze zależało od wykształcenia sporządzających dokumenty, jak i od tworzenia języka polskiego i zastępowania słów łacińskich polskimi. Zmiany związane $\mathrm{z}$ pisownią nazwy miejscowości przysporzyły badaczom wielu trudności z ustaleniem metryki źródłowej Mikluszowic. Za najstarsze dokumenty dotyczące Mikluszowic uważa się jednak dokumenty polskie znajdujące się w Watykanie, a dotyczące świętopietrza. Pierwsze zapiski datowane są na lata $1325-1327$. Świętopietrze płacil wtedy Jakub, pleban z Niculaussowicz i Niculauschowicz!

Nazwa miejscowości Miclussovicze wymieniona w rachunkach z 1346 roku bardziej już przypomina dzisiejszą nazwę $e^{2}$. Na tym przykładzie łatwo się przekonać, że Mikluszowice to nazwa patronimiczna, utworzona od nazwy osobowej $\mathrm{Ni}$ colai, która uległa spolszczeniu i powstał Miklusz ${ }^{3}$.

Dolina Raby, w której położone są Mikluszowice, do niedawna uważana była za obszar stosunkowo późno zaludniony. Jednak przeprowadzone w ostatnich latach badania archeologiczne zdecydowanie tę tezę obaliły. Dogodne warunki naturalne - urodzajne mady, bliskość wody oraz puszczy - przemawiają za tym, że w wiosce mieszkali ludzie już w starożytności i wczesnym średniowieczu. Warto przy tym zwrócić uwagę i na to, że w późnym średniowieczu wydobywano

\footnotetext{
${ }^{1}$, Monumenta Poloniae Vaticana, wyd. J. Ptaśnik, t. I, Kraków 1913, s. 205.

${ }^{2}$ Tamże, t. II, s. 193

${ }^{3}$ P. G a las, Sredniowieczne nazwy terenowe Ziemi Bocheńskiej, „Onomastica” 1958,
} s. 255. 
sól w Bochui, którą przewożono między innymi wzdłuż brzegów Raby do Uścia Solnego, które posiadało prawo składu ${ }^{4}$.

Od najdawniejszych czasów osada była własnością rycerską, wskazuje na to końcówka jej nazwy „-cze”, a później ,-ce”. Świadczą o tym również dokumenty. Pomimo żmudnych poszukiwań nie udało się jednak do tej pory ustalić, kto i kiedy założył wieś. Wiadomo tylko, że pierwszymi właścicielami Mikluszowic byli Jan i Świętosław z Drwini ${ }^{5}$.

Na przestrzeni kilkuset lat Mikluszowice były własnością różnych rodów rycerskich. Dnia 11 kwietnia 1499 roku zostały sprzedane wraz z Dziewinem i częścią Drwini przez Mikołaja i Stanisława królowi Janowi Olbrachtowi za 1300 grzywien ${ }^{6}$. Od tego czasu aż do I rozbioru Polski były w rękach władców. Po I rozbiorze, podobnie jak wszystkie dobra królewskie tej części Polski, również i Mikluszowice znalazły się w rękach austriackich, a dokładnie 25 kwietnia 1773 roku przyłączono je do funduszu religijnego?. Włączenie wioski do tegoż funduszu powodowało, że i ta społeczność była bezpośrednio zarządzana przez władze krajowe. Ludność tu zamieszkująca zajmowała się głównie rolnictwem. Nie brakowało też ogrodników i różnego rodzaju rzemieślników.

Życie społeczno-gospodarcze i kulturalne w Mikluszowicach było i jest ściśle zwiazane na przestrzeni wieków z Kościolem i szkoła. Podobnie jak trudno ustalić datę powstania miejscowości, tak samo trudno podać dokładną datę wybudowania pierwszego kościoła. O budynku kościelnym w Mikluszowicach nie wiadomo nic aż do 1440 roku. Tylko dzięki Długoszowi dowiadujemy się, że w wiosce był kościół ${ }^{8}$. Natomiast pierwsza wzmianka źródłowa dotycząca szkółki parafialnej znajduje się w aktach wizytacyjnych z 1590 roku'. Pierwszym kierownikiem szkoły był Zygmunt z Mikluszowic. Następni nauczyciele mikluszowscy między 1596 a 1620 rokiem to: Martinus Rektor Scholae i Stanislaus Cantor ${ }^{10}$.

Pierwszą szkołę $\mathrm{z}$ prawdzıwego zdarzenıa wybudowano w 1846 roku, a przetrwała ona prawie do dzisiejszych czasów ${ }^{11}$. Do tej właśnie szkoły uczęszczał ks. Józef Bardel, tutaj uczył się również religii, tu kształtowały się - jego charakter i osobowość. Obecnie w Mikluszowicach wybudowany jest okazaly budynek szkolny, z wymogami na dzisiejsze czasy, a poprzedni budynek, o którym mówiliśmy, został rozebrany ${ }^{12}$. Tak więc w skrócie przedstawilem środowisko rodzinne (wieś Mikluszowice) ks. Józefa Bardla. Nadszedł więc czas, aby w te długoletnie dzieje wsi włączyć nie tyle rodzinę, co cały ród Bardlów, a szczególnie ks. Józefa, któremu ten artykuł poświęcam.

${ }^{4}$ J. P i o trow i c z, Zupy krakowskie w pierwszych wiekach rozwoju od polowy XIII do poczctku XV! wieku [w] Dzicje żup lrakowskich red. A. Jodlowski, Wieliczka 1988, s. 137.

5 Zbiór dokumentów matopolskich. Materialy Stownika historyczno-geograficznego województwa krakowskiego, wyd. S. Kuraś, J. Sułkowska-Kuraś, cz. IV, Kraków 1969, s. 136.

${ }^{6}$ Tamże, s. 145.

${ }^{7}$ K. C zemeryński, O dobrach koronnych bytej Rzeczypospolitej Polskiej, Lwów 1870 , s. 127

${ }^{8}$ Liber beneficjorum diaecesis Cracoviensis, wyd. A. Przeździecki, t. I s. 77, s. 162.

${ }^{9}$ S. Kot, Szkolnictwo parafialne w Matopolsce w XVI-XVIII wieku, „Muzeum. Dodatek” 8, R. XXVII, 1911, s. 290.

${ }^{10} \mathrm{~J}$. Przy b o r o w s k i, Z dziejów jednej wsi, Busko Zdrój 1964, s. 137.

${ }^{11}$ Ł. P i ą t k ow s k a, Dzieje Mikluszowic (1326-1914), Kraków 1998, s. 70.

12 Tamże, s. 72 
Trudno podać dokładną datę, kiedy członkowie rodu ks. Józefa Bardla przybyli do Mikluszowic i skąd to nazwisko się wywodzi. Przedstawiciel rodu, ks. Franciszek Burdel (tak pierwotnie brzmiało nazwisko rodu), w jednym ze swoich listów z Anglii podaje taką informację: „Otóż za czasów Zygmunta Starego i Władysława jego syna około 40 tysięcy tak Szkotów, jak i Anglików, katolików, opuściło swoją ojczyznę w czasie srożenia się prześladowania Kościoła za czasów króla Henryka VIII i jego córki Elżbiety I i schroniło się do Polski jako kraju katolickiego i bardzo tolerancyjnego. A kiedy szły raporty do króla polskiego, by raczył wyrzucić uchodźców z Polski, to otrzymał odpowiedź, że Polska nie jest tylko ojczyzną dla swoich dzieci, ale i dla tułaczy, którzy nie mogą się pogodzić z narzuconymi przez tamtejszego króla prawami, zwłaszcza gdy chodzi o sumienie $\mathrm{i}$ ich przekonania religijne (...). A co się tyczy naszego nazwiska, to ono w Anglii jest bardzo znane i ja miałem $z$ tego powodu dużo ułatwień, bo mnie brano za Anglika. Nasze nazwisko wymawiali Bardel i akcent dawano na literę «e» (...). Ponieważ Anglicy i Amerykanie wiele słów skracają i ułatwiają sobie ich pronuncję czyli wymowę, więc zamiast litery «a» wymawiano «o» (Bordell). A w Polsce, jak to wszystko ludzie mazurza, znowu zamiast «a» lub «o» wymawiali «u», czyli to słowo ohydne w naszej mowie: Burdel. W Polsce spotykamy nazwiska wywodzące się od naszego rodu (Bartel, Bardlewski, Bartlewski, Barglewski)"13. Jak z tego wynika, nazwisko rodu Bardlów wywodziło się z Anglii. Kiedy rzeczywiście członkowie rodu osiedlili się na tym terenie, trudno podać dokladną datę. Są i takie spekulacje, ze pierwszą miejscowością gdzie osiedli przedstawiciele rodu ks. Józefa Bardla, była niedaleka miejscowość Uście Solne ${ }^{14}$. Za tą wersją przemawiał łatwiejszy dostęp do wioski w owym czasie. Nie znalazłem jednak na to jasnych dowodów. O tym jednak, że ród Bardlów zamieszkał najpierw w Mikluszowicach, świadczy chociażby to, że parafia Mikluszowice powstała najprawdopodobniej w XII wieku, a księgi metrykalne istnieja od 1569 ro$\mathrm{ku}^{15}$. Uście Solne natomiast jest parafią od 1360 roku, zaś wpisy do ksiąg metrykalnych są prowadzone od 1731 roku $^{16}$. Badając drzewo genealogiczne rodu Burdlów w Mikluszowicach, udało mi się dotrzeć w księgach metrykalnych do daty 1770 i 1773, czyli do dat urodzin pradziadka ks. Józefa Bardla, Marcina Burdla, organisty parafialnego i kierownika miejscowej szkoły oraz prababki - Apolonii Herc (1773). W księgach metrykalnych parafii Uście Solne nazwisko Bardel figuruje od 1803 roku ${ }^{17}$. Należy w tym miejscu zaznaczyć, że wspomniany ks. Franciszek Burdel, krewny ks. Józefa Bardla, urodził się w Lipnicy Murowanej. To nazwisko zatem figuruje również w tamtejszych księgach metrykalnych. Ale nie tylko. Przedstawiciel tego rodu, Karol Bardel, do którego udało mi się dotrzeć, mieszka także w Barcicach. Przedstawiciele rodu Bardlów zamieszkiwali zatem następujące miejscowości: Mikluszowice, Uście Solne, Lipnicę Murowaņ, Barci-

\footnotetext{
${ }^{13}$ Relacja ks. Franciszka Burdla, Londyn 31 marca 1956 roku.

${ }^{14}$ Informację taką podają przedstawicielki rodziny ks. Józefa Bardla Anna i Zofia Pawfowskie z Tarnowa.

${ }^{15}$ Schematyzm Diecezji Tarnowskiej, Tarnów 2000, s. 106-107.

${ }^{16}$ Tamże, s. 596-597.

${ }^{17}$ Zob. Księgi metrykalne parafii Mikluszowice oraz parafii Uście Solne.
} 
ce, Tarnów, Warszawę i Londyn. A może jeszcze i inne, do których nie udało mi się dotrzeć.

Ks. Józef Bardel urodził się 7 lipca 1884 roku w Mikluszowicach jako szóste z dziesięciorga dzieci. Był synem Franciszka i Marianny Majta, średniozamożnych gospodarzy ${ }^{18}$. Z rodem tym związane były zasłużone dla ojczyzny i Kościoła osoby. Wspomniany powyżej Marcin Burdel, organista i kierownik szkoły, kuzyn Adam, a szczególnie jego dzieci: Franciszek Bardel - doktor prawa, Jan Bardel mecenas, Maciej Bardel, Jan Ptaśnik - historyk, którego brat Józef był mężem Katarzyny, córki Adama i kuzynki ks. Józefa Bardla. Nie brakowało także zasłużonych nauczycieli (żona mecenasa, Eleonora Nowak, Maria - 95-letnia córka Józefa Ptaśnika mieszkająca w Londynie, Mieczysław Ptaśnik, Franciszek Ptaśnik, czy wreszcie Józef Wieszczek, syn siostry ks. Józefa Bardla, Katarzyny. Do członków rodziny należał także wspomniany już ks. Franciszek Burdel.

W księgach metrykalnych w Mikluszowicach umieszczono adnotację informującą o zmianie nazwiska „Burdel” na „Bardel”. Adnotacja ta figuruje przy danych personalnych w księdze chrztów ks. Józefa Bardla oraz jego kuzyna Adama. W obydwu przypadkach jest to rok 1898. Przy nazwisku ks. Józefa jest zaznaczona data 2 maja, natomiast przy jego kuzynie - 20 sierpnia, na podstawie dokumentu nadesłanego do parafii Mikluszowice ze Lwowa ${ }^{19}$. Podobne adnotacje napotykamy również w księgach metrykalnych w Lipnicy Murowanej i Uściu Solnym.

W rodzinie Bardlów na pierwszym miejscu stawiano Boga, Kościół i - związane z tym - umilowanie ojczyzny. Kierowano się zasadą: „Módl się i pracuj”. Dom rodzinny ks. Józefa Bardla znajduje się w najstarszej części wioski, w pobliżu kościoła parafialnego, na tak zwanym Podkościelu. Został on wybudowany w charakterystycznym dla okolicy stylu architektonicznym. Dom zawsze przypominał i przypomina niewielkich rozmiarów dworek. Do jego wnętrza prowadziły drzwi chronione przez drewniany ganek. Ganek ten byl bogato zdobiony, a na to mogli sobie pozwolić jedynie zamożni mieszkańcy Mikluszowic. Jak wspominają najstarsi żyjący mieszkańcy wsi, w bezpośrednim otoczeniu domu znajdował się trawnik, ogród różany oraz kilka drzew owocowych. Dzisiaj tak zwana Bardlówka jest mocno zaniedbana. Niestety, nikt z najbliższej rodziny ks. Józefa Bardla nie żyje, żyją już tylko bardzo dalecy krewni, którzy mieszkają poza Mikluszowicami.

\section{EDUKACJA}

Ks. Józef Bardel w wieku 7 lat rozpoczął naukę w miejscowej szkole powszechnej. Nauka trwała 6 lat. Niestety, prawdopodobnie nie zachowały się do dziś dokumenty dotyczące nauczycielı czy osiaganych przez niego wyników w nauce. Nie ulega natomiast watpliwości, że duży wpływ na wychowanie chłopca mieli pracujący w owym czasie w Mikluszowicach kapłani: ks. Jan Figwer, proboszcz mikluszowickiej parafii, a wcześniej kanclerz Kurii Diecezjalnej w Tarnowie, ks. Henryk Rampert, również proboszcz, oraz katecheci: ks. Józef Łopata i ks. Józef Rodoniewicz, który ochrzcił swego imiennika i przyszłego księdza Józefa Bardla.

\footnotetext{
${ }^{18}$ Liber natorum, Mikluszowice 1884, t. III, s. 78.

${ }^{19}$ Tamże.
} 
Z relacji najstarszych mieszkańców Mikluszowic wynika także, iż mały Józio był żywym i pełnym energii chłopcem. Z pewnością musiał się też odznaczać zdolnościami do nauki, skoro - po ukończeniu szkoły powszechnej-podobnie jak wielu jego rówieśników, rozpoczął naukę w bocheńskim gimnazjum, które w owym czasie uchodziło za jedno z najlepszych w całej Galicji.

Przyjrzyjmy się zatem pokrótce owemu gimnazjum i związanej z nim bursie, jego nauczycielom i wychowankom, szczególną uwagę zwracając na będącą głównym przedmiotem naszego zainteresowania postać ks. Józefa Bardla.

Gimnazjum w Bochni, jak już wspomuieliśmy, przeżywało w owym czasie okres rozkwitu. W roku 1886 oddano do użytku nowy budynek szkolny. To ułatwiło podniesienie szkoły do rangi gimnazjum wyższego, co wiązało się z jego przekształceniem ze szkoły czteroklasowej na ośmioklasową. Fakt ten zdecydowanie wpłynął na prestiż szkoły. Istotnym momentem, rzutującym na rozwój bocheńskiego gimnazjum na przełomie XIX i XX wieku były również dążenia do reformy kształcenia i wychowania w szkołach średnich. Te nowe warunki sprzyjały, aby więcej uczniów z okolicznych wsi - zwłaszcza tych utalentowanych mogło korzystać z nauki 20 .

Na szczególną uwagę zasługują tu nauczyciele i wychowawcy, dzięki którym bocheńskie gimnazjum cieszyło się w owym czasie takim powodzeniem. Absolwent gimnazjum, Józef Ostrowski, który maturę zdawał w 1892 roku, a którego rękopis pamiętników znajduje się w Bibliotece Jagiellońskiej tak wspomina niektórych profesorów: „Funkcję dyrektora pełnił Michał Żułkiewicz, nauczyciel języka greckiego. Był człowiekiem zapobiegliwym, starannym i uczynnym. Chciał, aby młodziez sprawowała się wzorowo i skrupulatnie wypełniała swoje obowiązki. Dbał o młodzież i troszczył się o nią, jakby chodziło o jego własną rodzinę. Zatroskany o naukę śpiewu i gry na instrumentach, w czasie wakacji 1889 wsiadł na wózek i objeżdżal całą okolicę, od domu do domu, od proboszcza do proboszcza, i - kwestując - utworzył fundusz na zakup instrumentów muzycznych. Tak powstała kapela gimnazjalna. Szczególną troską otaczał biednych studentów. Gdy ktoś potrzebowal czegoś, na przykład podrecznika do nauki, potrafił pojechać nawet do Krakowa, aby tam nabyć i pożyczyć"2!. Był nauczycielem wymagającym od siebie, ale i od drugich. Uczył nie tylko języka, ale również wskazywał uczniom, jak żyć.

Ks. Józef Bardel miał szczęście być uczniem i innych wybitnych osobowości. Należeli do nich współpracownicy dyrektora Zułkiewicza, tacy jak: Henryk Trzpis nauczyciel języka polskiego, Ryszard Ordyński - nauczyciel języka niemieckiego, Ludwik Tola - nauczyciel łaciny, Stanisław Matwij - nauczyciel greki, Wawrzyniec Waśkowski - historyk i geograf, Roman Jamrógiewicz - matematyk i fizyk, czy wreszcie ks. Alojzy Nalepa - nauczyciel religii i pierwszy prefekt bursy ${ }^{22}$.

„Stanisław Matwij, nauczyciel języka greckiego odznaczał się trwałą pogodą ducha, wyrozumiałością i dobrocią. Umiał pogodzić swoje obowiązki nauczyciel-

${ }^{20} \mathrm{C}$. M ajorek, W. M a rmon, Gimnazjum bocheńskie w okresie niewoli narodowej, [w:] F. Kiryk (red.), Bochnia. Dzieje miasta i regionu. 170 lat Gimnazjum w Bochni, Bochnia 1988 , s. 20-23.

${ }^{21}$ Odpis rękopiśmienniczy Janiny Kęsek, s. 3-5.

${ }^{22}$ Informacje te pochodzą $z$ relacji pisemnej Janiny Kęsek oraz świadectwa maturalnego ks. Józefa Bardla z 1905 roku. 
skie z obowiązkami uczniów i nigdy ich nie przeciążał, był bowiem dla młodzieży zawsze przyjacielsko usposobiony. Był bardzo wyrozumiałym dla uczniów. (...) Długie lata pozostawałem $z$ kochanym profesorem $w$ korespondencji, bo był dla mnie serdecznie życzliwym, a prócz tego stanowił żywy pomnik dawnych młodych, stokroć lepszych czasów,"23.

Młodszy o dwa lata od ks. Józefa Bardla Jan Gębica, po II wojnie światowej nauczyciel języka polskiego w tej szkole, wspominal: „Do Gimnazjum im. Kazimierza Wielkiego w Bochni uczęszczałem w latach 1899 do 1907 (...). Uczyliśmy się języka łacińskiego już od klasy pierwszej, a greckiego od trzeciej. W gimnazjum ówczesnym przeważały przedmioty humanistyczne. Wymagania były duże. Trzeba było pilnie pracować, żeby zdobyć «pasek» do następnej klasy. Gdy uczeń skończył czwartą klasę, na miejsce czterech srebrnych pasków otrzymywał jeden złoty, a w klasie ósmej nosił na kołnierzyku cztery złote paski.

Jeżeli chodzi o profesorów, to doskonale pamiętam polonistę Henryka Trzpisa, germanistów - Ryszarda Ordyńskiego i Franciszka Tyczkę, filologów: Totę i Matwija, biologów: Szklarzewicza i Bielczyka, historyka Waśkowskiego. Matematyki i fizyki uczył nas Franciszek Słuszkiewicz, późniejszy dyrektor tego gimnazjum.

Dyrektor Żułkiewicz był już za moich czasów człowiekiem starszym i bardzo przez nas poważanym. Rzadko chodził na hospitacje, przeważnie przebywał w kancelarii, do której każdy uczeń wchodził z biciem serca. Pilnował porządku, a w razie nieobecności jakiegoś nauczyciela sam prowadził lekcje. (...) Dyrektor Żułkiewicz był założycielem bursy gimnazjalnej, w której znajdowała pomieszczenie grupa uczniów zamiejscowych, przeważnie ze wsi. Płacili oni niewiele, częściej dostarczali produktów żywnościowych. Niezamożni mieli w bursie bezpłatne utrzymanie. (...) Nauka muzyki i śpiewu była nadobowiązkowa, ale młodzież garnęła się do tych zajęć chętnie. Uczył tych przedmiotów Antoni Langer, Kapelmistrz Orkiestry Salinarnej. Mieliśmy przygotowany cały szereg pieśni religijnych, patriotycznych i okolicznościowych. (...) Do ukochanych moich nauczycieli należeli: prof. Henryk Trzpis, który uczył nas języka polskiego w wyższym gimnazjum, i prof. Ryszard Ordyński, wychowawca i nauczyciel języka niemieckiego. Prof. Trzpis był entuzjasta romantyzmu i Młodej Polski, uwielbiał zwłaszcza poezje Słowackiego. (...) Prof. Trzpis był dla nas powaga naukowa, zawsze przygotowany do lekcji, wykładał interesująco. Był surowy, wymagający, ale wyrozumiały. Umiał zachęcić młodzież do swojego przedmiotu, który kochaliśmy podobnie jak historię kraju rodzinnego, wykładaną jako przedmiot nadobowiązkowy, na ostatnich lekcjach, na które jednak wszyscy uczęszczali. (...)

Drugim moim ukochanym profesorem był nasz wychowawca, Ryszard Ordyński. W nauce literatury niemieckiej interesował się glównie utworami dramatycznymi. Jeździł z nami do teatru na ciekawsze sztuki i równocześnie zaznajamiał nas $z$ nowoczesnymi prądami w literaturze światowej. On pierwszy zwrócił nam uwagę na „Współczesną literaturę” Feldmana, radził ją czytać i poznawać jej przedstawicieli. Ordyński był zaprzyjaźniony ze starszym od siebie o 10 lat Stanisławem Wyspiańskim i lubił nam o nim opowiadać. (...) Po maturze dowiedziałem się, że zamierza rozstać się z zawodem nauczyciela, by poświęcić się całko-

${ }^{23}$ M. O s trow s k i, Na przełomie wieków. Autograf wspamnień z lat $1881-1928$, t. I, Biblioteka Jagiellońska, Sygn. rękopisu 9117 II. 
wicie teatrowi. (...) Jego uprzejmość, delikatność i zdolność sprawily, że miał wielu przyjaciół wśród wybitnych ludzi, takich jak: Reinhardt, Shaw, Craig, Stanisławski, Antoine, Chaplin, Solski, Osterwa, Schiller. (...) Nigdy nie zapomnę lat spędzonych w gimnazjum bocheńskim i jestem szczęśliwy, że mogę uczyć w tej samej szkole"24.

Nie wiemy, co by o tych profesorach powiedział sam ks. Józef Bardel, bo ci sami i jego uczyli. Niestety, już się nie dowiemy. Nie ulega natomiast żadnej wątpliwości, że to były najważniejsze postaci w historii tej szkoły w tym czasie, których osobowość miała wielki wpływ na kształtowanie charakteru młodego Bardla. $\mathrm{O}$ innych nauczycielach nie ma specjalnych wiadomości i nie są wspominani w uczniowskich pamiętnikach. Można stąd wysnuć wniosek, że nauczyciele ci niczym szczególnym w pamięci uczniów się nie odznaczyli.

$Z$ historią gimnazjum bocheńskiego ma ścisły związek bursa, miejsce, gdzie młodzież - zwłaszcza z odległych miejscowości - która wcześniej przemierzała pieszo kilometry dzielące ją od szkoły lub mieszkała na stancjach, mogła zamieszkać i mieć godziwe warunki do nauki. Do powstania tego budynku przyczynił się sam dyrektor Michał Żułkiewicz. Ileż było o to jego starań. Nawet sam w tym celu objeżdżał okoliczne dwory, kwestując na ten szlachetny cel $^{25}$. Sam ks. Józef Bardel mieszkał przez 6 lat na pięciu różnych stancjach. Jak się tam zachowywał, niestety, nie udalo się dotrzeć do mieszkańców tych budynków ${ }^{26}$. Bursę oddano do użytku w roku szkolnym 1901/1902. Ks. Józef Bardel natomiast ukończył szkołę w roku 1904/1905. Nie było łatwo dostać się do bursy. Początkowo na miejsce mogli liczyć jedynie najlepsi uczniowie, ale decyzje zmieniono, przyjmowano warunkowo i słabszych uczniów, stwarzając warunki do poprawy i właściwego rozwoju ${ }^{27}$.

Nie ma pewnych informacji, czy ks. Józef Bardel przez ostatnie dwa lata nauki mieszkał w bursie, dojeżdżał czy dochodził do szkoły, na arkuszach ocen $z$ tych ostatnich dwóch lat nie ma o tym żadnej wzmianki. Główny nadzór nad bursą sprawował osobiście dyrektor Michał Zulkiewicz, a jej pierwszym prefektem i nauczycielem religii $\mathrm{w}$ gimnazjum $\mathrm{w}$ tym czasie był wielce zasłużony dla Kościoła i Ojczyzny ks. Alojzy Nalepa. To, czym sam żył, pieczołowicie przekazywał innym. Wychowywał młodzież $w$ duchu religijnym i patriotycznym ${ }^{28}$, kontynuując dzieło swego poprzednika, katechety. Wcześniej był prefektem i wicerektorem Wyższego Seminarium Duchownego w Tarnowie ${ }^{29}$.

Ks. Alojzy Nalepa był niezrównanym gospodarzem i niedoścignionym wychowawca, uważał bursę za dom, aby każdy wychowanek bursy czuł się zadowolony. Troszczył się o chorych. Opiekował się nimi jak dobra matka. Nic więc dziwnego, że z tej szkoły wyszedł cały szereg kapłanów i młodzieży o przekonaniach i światopoglądzie chrześcijańskim i o wyrobionym poczuciu odpowiedzial-

${ }^{24}$ J. G ę bic a, Moje wspomnienia szkolne, „Komunikat Stowarzyszenia Bochniaków i Miłośników Ziemi Bocheńskiej"1 1967 nr 24.

${ }^{25}$ M. Ostrowski, dz. cyt.

${ }^{26} \mathrm{~J}$. K ę s e k, Bursa gimnazjalna i kościót szkolny w Bochni, „Rocznik Bocheński” t. V, 2001, s. 198.

${ }^{27}$ A. W e is s, Kronika Towarzystwa Bursy Gimnazjalnej im. A. Mickiewicza w Bochni, Bochnia 1905, s. 14

${ }^{28}$ J. K ę s e k, Bursa..., dz. cyt., s. 200.

${ }^{29}$ Schematyzm Diecezji Tarnowskiej 1992, s. 64, 89, 127. 
ności ${ }^{30}$. O tym, kim był ks. Alojzy Nalepa dla młodzieży miasta i regionu, świadczy tablica w bursie, która - odsłonięta 16 stycznia 1929 roku - zawiera następującą inskrypcję: „Ks. Alojzemu Nalepie, katechecie gimnazjalnemu i prefektowi bursy w Bochni, zmarłemu 16 stycznia 1928 roku, ojcu i opiekunowi młodzieży, którą przez 25 lat wychowywał na wiernych synów Kościoła i Ojczyzny, ten kamień kładą wychowankowie i przyjaciele" ${ }^{31}$. Nic dziwnego, że na jego pogrzebie było stu kapłanów i wielotysięczny tłum. A na mogile rodzice wychowanków umieścili skromny pomnik ze znamienną inskrypcją: „Za pieczę ojcowską nad dziećmi naszymi wieczną światłością niech nagrodzi Bóg" ${ }^{\prime 32}$.

Tablicą umieszczoną na frontowej ścianie budynku bursy upamiętniono także zasługi Michała Żułkiewicza. Na wmurowanej pośmiertnie tablicy ku czci założyciela znajdował się napis: „Michałowi Żułkiewiczowi, Dyrektorowi Gimnazjum w Bochni w uznaniu niespożytych zasług około założenia bursy - Towarzystwo Bursy im. A. Mickiewicza w roku $1905^{33}$.

Jakim uczniem był ks. Józef Bardel? Na podstawie wspomnianych wcześniej arkuszy ocen można stwierdzić, że był dobrym uczniem. Trzeba jednak wspomnieć, iż choć języka niemieckiego uczył go, wspomniany już wcześniej, znakomity pedagog Ryszard Ordyński, to jednak z tego przedmiotu miał słabe oceny.

Śledząc fragment historii bocheńskiego gimnazjum w okresie, w którym uczył się w nim ks. Józef Bardel, nie sposób nie zauważyć, że - mimo niesprzyjających warunków egzystencji w okresie niewoli narodowej - szkoła bocheńska dała Polsce wielu wybitnych uczonych, artystów i ludzi zasłużonych na niwie politycznej. Grono absolwentów z przełomu XIX i XX wieku, kiedy szkoła przeżywała swój rozkwit, przedstawia się imponująco. Na uwagę zasługują tacy ludzie nauki, jak: Franciszek Bujak, Roman Grodecki, Ludwik Piotrowicz, Jan Ptaśnik, Kazimierz Kaczmarczyk, Karol Piotrowicz, Józef Seruga. W zakresie medycyny sądowej odznaczył się Jan Olbrycht, w polityce działał Władysław Kıernık, a w dziedzinie sztuki: Karol Frycz, Marcin Samlicki, Władysław Skoczylas, Bogusław Serwin, Antoni Waśkowski. Poza wspomnianymi był jeszcze cały szereg innych duchownych, nauczycieli lekarzy, prawników, urzędników - którzy swoim życiem zapisali się na trwałe w dziejach polskiego społeczeństwa ${ }^{34}$. Wśród nich nie mogło zabraknąć również przedstawicieli rodu Bardlów, a przede wszystkim będącego głównym przedmiotem naszego zainteresowania - ks. Józefa Bardla.

Po ukończeniu ośmioletniego gimnazjum w Bochni i pomyślnym zdaniu matury ze średnią ocen na świadectwie maturalnym 4,5 Józef Bardel podjął studia filozoficzno-teologiczne w Seminarium Duchownym w Tarnowie. Być może na podjęcie takiej decyzji miało wpływ uczestnictwo w pielgrzymce młodzieży polskiej do Rzymu, którą prowadził arcybiskup lwowski, bł. Józef Bilczewski ${ }^{35}$.

Podobnie jak wcześniej w gimnazjum, tak i w seminarium duchownym mial ks. Józef szczęście do znakomitych pedagogów. Seminarium było wówczas przedmiotem szczególnej troski Ordynariusza Tarnowskiego ks. bp. Leona Wałę-

\footnotetext{
${ }^{30}$ A. U r b a ń s k i, Bursa gimnazjalna im A. Mickiewicza w Bochni, Bochnia 1977, s. 47-48.

${ }^{31}$ Cyt. za "Głos Narodu” 1929 nr 20, s. 3.

${ }^{32}$ Cyt. za J. K ę s e k, Bursa..., dz. cyt., s. 204.

${ }^{33}$ Tamże, s. 201.

${ }^{34}$ C. Ma jor e k, W. M armo n, dz. cyt., s. 33.

${ }^{35}$ Zob. B. K u m o r, Historia parafii Trzetrzewina, mps Archiwum parafii Trzetrzewina.
} 
gi, który bardzo starannie - po wielu przemyśleniach i konsultacjach - dobierał do niego kadrę przełożonych, formujących przyszłych kapłanów. Jak wspominają pamiętajacy biskupa kapłani, zależało mu na tym, aby mieć świętych kapłanów. Bardzo dużo w tej intencji się modlił. W trosce o ilość powołań kapłańskich udał się także do Tuchowa, aby tam prosić Matkę Bożą w tej intencji. Podczas modlitwy swój biskupi pastorał złożył przed wizerunkiem Matki Bożej Tuchowskiej.

Przełożonym ks. Józefa Bardla był doktor prawa kanonicznego ks. Stanisław Jan Dutkiewicz, który pełnił funkcję rektora. On to przeprowadził gruntowny remont gmachu seminaryjnego. Zasłużył się wypracowaniem swoistego stylu świętości kapłanów. Wicerektorem był ks. dr Michał Rec, który wielka troską otaczał nie tylko cale seminarium, ale każdego kleryka z osobna. Ojcem duchownym był natomiast ks. Kasper Mazur. To właśnie jego harmonijna współpraca $\mathrm{z}$ rektorem na dhugie lata wytworzyła pewien styl świętości kapłańskiej w diecezji tarnowskiej. Obowiązki prefektów pełnili: ks. Jan Dulian oraz ks. dr Stanisław Wróbel profesor teologii fundamentalnej.

Profesorami ks. Józefa Bardla byli: ks. dr Stanisław Dutkiewicz - wykładowca Nowego Testamentu, ks. Walenty Gadowski - profesor katechetyki, metodyki i pedagogiki, autor wielu podręczników nauki religii i publikacji teoretycznych z tej dziedziny, wielki miłośnik gór, współtwórca szlaków: Orlej Perci w Tatrach i Sokolej Perci w Pieninach. Historii Kościoła uczył ks. dr Jakub Górka, dogmatykę oraz filozofię wykładał ks. dr Andrzej Macko. Liturgiką zajmował się wspomniany wcześniej ojciec duchowny Kasper Mazur, zaś śpiewu uczył ks. Florian Moryl. Teologii pastoralnej i homiletyki uczył ks. dr Jakub Stanczykiewicz, wykładowcą Pisma Swiętego Starego Testamentu był ks. Tomasz Włoch, zaś teologii fundamentalnej i filozofii scholastycznej uczył ks. dr Michał Zyguliński, człowiek głęboko wrażliwy na krzywdę drugich oraz niezwykle uzdolniony ${ }^{36}$.

To w takim właśnie środowisku przyszły kapłan - pod czujnym okiem przełożonych i profesorów - zgłębiał tajemnicę Boga, poznawał Go i bardziej miłowal, poznawał historię Kościoła i związaną z nim historię poszczególnych narodów, a w szczególności - historię Polski. Tutaj uczył się modlitwy oraz tego, jak łączyć modlitwę z pracą. Widać, że poważnie podchodził do rozwoju swojego powołania w pełnym tego słowa znaczeniu. Świadczą o tym oceny, jakie otrzymywał w seminarium, wśród których były prawie same eminens, a niekiedy bardzo dobry ${ }^{37}$.

Ks. Józef Bardel uwieńczył swoje studia filozoficzno-teologiczne święceniami kapłańskimi, których jemu i jego dwudziestu kolegom udzielił Biskup Tarnowski Leon Wałęga 29 czerwca 1909 roku $^{38}$.

${ }^{36}$ Schematyzm Diecezji Tarnowskiej 1992, s. 26, 57, 65, 78, 87, 91, 103, 105, 107, 126, $138,144,146-147$.

${ }^{37}$ Archiwum Seminarium Duchownego w Tarnowie - Matricula Studiosorum S. Theologia in Instituto Theologico Dioecesano Tarnoviensi ab a 1893/94, s. 70-71.

38 A. N ow a k, Slownik biograficzny kaptanów diecezji tarnowskiej (1876-1985), t. II, s. 38; Schematyzm Diecezji Tarnowskiej 1909, s. 36-37. 


\section{PRACA DUSZPASTERSKA}

Pierwszą placówką duszpasterską neoprezbitera ks. Józefa Bardla była parafia Gręboszów. Zanim został proboszczem, pracowal na kilku placówkach, najczęściej w charakterze administratora. Tak było na przykład w czasie jego pracy katechetycznej w Czchowie, gdzie przez pewien czas excurrendo czyli ,z dojazdu” pełnił funkcję administratora w pobliskiej Złotej. Podobną funkcję pełnił w Lisiej Górze, Porębie Radlnej i wreszcie w Trzetrzewinie, gdzie 10 maja 1925 roku został pierwszym proboszczem nowo utworzonej parafii. Wikariuszem był zatem jedynie przez trzy lata na pierwszej placówce w Gręboszowie oraz przez niespełna rok w Czchowie i Tuchowie ${ }^{39}$.

Używając słów cytowanej wcześniej Janiny Kęsek, absolwentki bocheńskiego gimnazjum, która pisze, że ks. Józef Bardel miał szczeście do wspaniałych pedagogów w gimnazjum i w seminarium duchownym, trzeba powiedzieć, że mial też szczęście do wspaniałych księży proboszczów. Należeli do nich: ks. Piotr Halak, ks. dr Ignacy Maciejowski, ks. Józef Stopa oraz ks. Wojciech Bryndza ${ }^{40}$. Pierwszy z nich, zmarły w opinii świętości, kierowal parafią, która wydała wielkich ludzi, takich jak: Jakub Bojko, Henryk Sucharski czy Stefania Łącka. Ten pierwszy, za pośrednictwem ks. Piotra Halaka nawrócił się, a pozostali dojrzewali do pobożności i świętości ${ }^{41}$. Kolejny, ks. dr Ignacy Maciejowski, był wcześniej profesorem teologii moralnej i wykładowcą Pisma Świętego w Seminarium Duchownym w Tarnowie. Ks. Wojciech Bryndza był natomiast budowniczym kościoła w nowopowstałej parafii, współuczestniczył w budowie szkoły i poczty, był współzałożycielem kółka rolniczego oraz Kasy Stefczyka. W opinii parafii pozostał „kapłanem silnej wiary i prostego serca”. Gorliwym duszpasterzem był również ks. Józef Stopa ${ }^{42}$.

Zachodzi pytanie, jakim ks. Józef Bardel był katecheta, administratorem czy w końcu proboszczem? Niestety, poza wpisami do ksiag metrykalnych w parafiach, gdzie pracował, nie udało się natrafić na czynione przez niego zapiski. W niektórych parafiach kroniki zaginęły, w innych o ks. Józefie Bardlu nie ma żadnych wzmianek. Zaginęła również kronika pisana przez niego samego podczas proboszczowania w Trzetrzewinie. Jedynie w kancelarii parafialnej w Tuchowie umieszczono adnotację dotyczącą ks. Józefa Bardla o następującej treści: „rozstrzelany 1941 przez Niemców w Biegonicach k. Nowego Sącza jako proboszcz z Trzetrzewiny razem z 2-ma księżmi wikarymi z Nowego Sącza ks. Kaczmarczykiem i ks. Deszczem oraz 40 obywatelami z Nowego Sącza. Ekshumowany i pochowany w Trzetrzewinie." Do notatki został dołączony dopisek w języku łacińskim „Tempore insectionis russiacae laborabat intrepide. Nunc expositus in Trzetrzewina” co oznacza: „W czasie prześladowanıa rosyjskıego pracował nieustraszenie. Teraz ekspozyt w Trzetrzewinie"43.

${ }^{39}$ Tamże, s. 38.

${ }^{40}$ Schematyzm Diecezji Tarnowskiej 1992, s. 245, 547, 227, 536.

${ }^{41}$ Tamże, s. 246.

${ }^{42}$ Informacje te zostały zaczerpnięte $\mathrm{z}$ Kroniki parafii Lisia Góra znajdującej się w archiwum tejże parafii.

${ }^{43}$ Chronologicus Conspectus, Tuchów, s. 29, p. 137. 
Również w jednym z opracowań dotyczących historii kościoła i cudownego obrazu Najświętszej Maryi Panny w Tuchowie udało się znaleźć następująca informację odnoszącą się do ks. Józefa Bardla: „Z chwilą najazdu wojsk rosyjskich w 1914 roku do Tuchowa, stosunek między wojskowością a pozostałymi kapłanami w Tuchowie coraz bardziej się zaostrzał. 26 marca 1915 roku wywieziono ks. Bardla. W kościele parafialnym nie było nabożeństw przez jakiś czas, cały ciężar pieczy nad parafią spadł na pozostałych w klasztorze ojcach, którzy ocaleli ${ }^{44}$.

Czasy są już odległe, nie ma więc takich ludzi, którzy by pamiętali ks. Józefa Bardla z pierwszych lat jego kapłaństwa. Dzięki żyjącemu 93-letniemu ks. Stanisławowi Pieprznikowi, obecnie najstarszemu kapłanowi w diecezji tarnowskiej, bardzo zaangażowanemu w przygotowanie monografii o swoim poprzedniku, który to utorował mu droge do pracy duszpasterskiej w Trzetrzewinie, udało się dotrzeć do żyjących świadków w parafii Trzetrzewina i ich słowa przybliżą nam postać ks. Józefa Bardla, ich pierwszego proboszcza, który pracował wśród nich od 15 marca 1917 roku do 2 lipca 1941 roku, a zatem ponad 24 lata.

Maria Lorek (lat 90) uczennica ks. Józefa Bardla, współpracowniczka w szkole i dyrektorka miejscowej szkoły wspomina: „Ks. Józef wymagał od siebie, od nauczycieli i od uczniów. Umiał powiedzieć prawdę w oczy. Dbał o swój wygląd, esteta wymagał od uczniów czystości. (...) Ks. Józef interesował się młodzieża, która uczęszczała do szkoły średniej. Byl w ciaglym kontakcie z gimnazjum, gdzie uczył jego przyjaciel ks. Jędrzej Ciemiak. Wtedy nie było tak jak dziś, był surowy rygor. (...)

Miał bardzo wielką wiedzę. Był również wielkim patriotą. Bezwzględny, wymagał nie tylko od siebie, ale i od innych. Głosił bardzo ladne kazania. Umiał się zachować elegancko, był towarzyski. Mimo, że słynął z surowości, dzieci go bardzo ceniły. (...) Jak zauważył zdolności ucznia, doradzał rodzicom, żeby posłali dziecko do lepszej szkoły: chłopców do gimnazjum, a dziewczęta - do seminarium nauczycielskiego. To jemu zmarły już ks. prof. Bolesław Kumor, historyk, zawdzięczał swoje wykształcenie. (...) Prowadził wspaniały chór, bardzo ładnie śpiewał. Był utalentowany pod względem muzycznym.

Prowadził również siedmiohektarowe gospodarstwo, w którym sam wiele pracował. Umiał sprytnie połączyć pracę w polu z obowiązkami duszpasterskimi. $\mathrm{Na}$ pracy w polu znał się doskonale. Potrafił stawiać wspaniałe kopy z siana (...) Dbał równocześnie o życie moralne parafii (...)".

Natomiast s. Kazimiera Zając, siedemdziesięciojednoletnia karmelitanka, była uczennica, wspomina: „Ks. Józef Bardel był bardzo gorliwy. Prosił z ambony, aby nie było „dzikich” małżeństw, aby się wierni nie spóźniali na Mszę święta, aby wszyscy śpiewali. Gdy chodził po kolędzie, pytał dzieci pacierza i katechizmu. Starsze dzieci pytał natomiast, jakie pieśni były śpiewane w kościele. Ks. Józef był mocnego fundamentu w postaci pewnej wiedzy, jasnej, w miarę zwięzłej jak katechizm (...).

Wanda Straszyńska-Skrzeszewska (z domu Ryś) 92-letnia nowosądeczanka mieszkająca w Warszawie pisze: „(...) Wieś ta (Trzetrzewina - J.K.) nie cieszyła się dobrą renomą. Tam ciagle były bijatyki, a ks. Bardel, nie ułomek, brał lagę i robił porządek. Wszyscy się go bali, ale szanowali". Na inne nieco sprawy zwra-

${ }^{44}$ W. S zoldrsk i, Historia kościola i cudownego obrazu NMP w Tuchowie, Cieszyn 1920, s. 166. 
ca uwagę w swoim wspomnieniu uczennica ks. Józefa Bardla, 86-letnia Rozalia Szczypuła: „Ks. Józef Bardel był człowiekiem modlącym się gorliwie i dobrym nauczycielem, wymagającym wiele od młodzieży - posłuszeństwa, dyscypliny. Był dobrym organizatorem (...). Organizował uroczystości patriotyczne 3 maja i 11 listopada. Według mnie był proboszczem nieodżałowanym".

Inny uczeń ks. Bardla, 75-letni Mieczysław Rodak, tak wspomina swego katechetę: , ,...) Pierwsze, co najbardziej dzisiaj pamiętam, to założenie róży żywego różańca, w której zostałem zelatorem, a w późniejszym czasie - ministrantem. Jak pamiętam z wygłoszonych kazań, to był kapłanem wymagającym, surowym, a zarazem patriota, i - jakbym to dzisiaj określił - więcej nadawał się na dyplomatę. Uważnie śledził wydarzenia polityczne w kraju i na świecie. Pamiętam także ubiór proboszcza, który zawsze przychodził na lekcje religii w kapeluszu, czarnym płaszczu i z laseczką w ręku (...).

Wspomnę jeszcze o jednym zdarzeniu. Było to w poniedziałek, w czwartym dniu wojny. Niemcy rozlokowali się na placu przykościelnym, postawili kuchnie i gotowali posiłki dla żołnierzy.. Było to rano, tuż po Mszy świętej. Ks. Józef wyszedł przed kościół i „szwargocąc” po niemiecku przegnał precz żołnierzy poza plac kościelny (...)".

Maria Góra, 89-letnia była uczennica, tak wspomina swego katechetę i proboszcza: ,(...) Jak byłam starsza, to dobrze pamiętam, że był człowiekiem dobrym, życzliwym, wspomagał biednych, bo przed wojną nie było za dobrze. Za ślub, którego mi udzielił, nie wziął ode mnie żadnych pieniędzy. W czasie wojny, kiedy ks. Bardel był aresztowany, nosiłam mleko do jednej pani w Nowym Sączu, która mieszkała blisko więzienia. Opowiadała, że jak wyprowadzano więźniów na rozstrzelanie, to psy gestapowskie szarpały ks. Bardla i gryzły. Był skrwawiony i posiniaczony (...). Kiedy dowiedzieliśmy się, że został rozstrzelany, zapanował w naszej parafii ogromny smutek $(. . .)^{3}$.

Ogromny patriotyzm ks. Józefa Bardla podkreśla w swoim wspomnieniu 75 -letni Jan Stawarski, również były uczeń: „Każde święto narodowe przygotowywal, urządzając $z$ tej okazji spotkanie. Pisał artykuły dotyczące ojczyzny do gazety lokalnej wydawanej w Nowym Sączu. Gazeta ta była rozprowadzana wśród parafian. Był bardzo wymagający, surowy. (...) Był organizatorem chóru, tworzył pieśni, komponował. Kazania głosił bardzo ładne. Był wrażliwy na dolę biednych, pomagał im. Zwracał uwage na bardzo dobre przygotowanie do sakramentu małżeństwa. Trzymał rygor, ale był bardzo lubiany w parafii, starał się tworzyć jej jedność. Troszczył się również o powołania kapłańskie i zakonne".

Oddajmy jeszcze głos Annie Tomaszek, również 75-letniej byłej uczennicy, która wspomina: „(...) Na lekcjach religii wymagał posłuszeństwa i karności oraz wiedzy na wybrane i omawiane tematy. Msze święte odprawiał z wielkım nabożenstwem i powaga. Kazania były bardzo dobitne i w sposób raczej prosty próbował przekazać parafianom, jak żyć według przykazań Bożych. Przy tym nie szczędził głosu (...). Ks. Bardel był zawsze życzliwy, serdeczny, lubił z każdym porozmawiać, a jeżeli to było w jego mocy, shużył radą i pomocą. Wszyscy, a na pewno większość parafian przeżyła bardzo boleśnie jego aresztowanie i śmierć, gdyż każdy - w mniejszy lub większy sposób - był z nim zżyty jako duszpasterzem" ${ }^{45}$.

${ }^{45}$ Wszystkie cytowane wspomnienia pochodzą ze zbiorów własnych autora. 
Nasuwa się na początku znów pytanie: co było bezpośrednią przyczyną uwięzienia i wreszcie tak okrutnej śmierci ks. Józefa Bardla? Dokumenty źródłowe wskazują na różne przyczyny. Przyjmuje się, że jedną była zemsta za likwidację nowosądeckiej grupy V Kolumny, założonej na rozkaz Hitlera organizacji przeznaczonej do prowadzenia w ościennych państwach działań szpiegowskich, sabotażowych i dywersyjnych, która z czasem objęła wszystkie kraje Europy, a także częściowo Amerykę, Azję i Afrykę.

W Nowym Sączu, który nazwany był „miastem kamym”, i na całej Sądecczyźnie działalność V Kolumny podjęła grupa osób, potomków niemieckich kolonistów osiadłych tutaj w czasach zaboru austriackiego, a którzy w okresie międzywojennym - jako ludzie inteligentni, pracowici i zdolni - pełnili odpowiedzialne funkcje we wszystkich gałęziach sądeckiej gospodarki. Mimo swoistego kamuflażu władze sądeckie zdołały rozpracować wrogą działalność. I tak 29 sierpnia 1939 roku sądecka policja aresztowała jedenastoosobowy aktyw V Kolumny. Zostali oni następnie wywiezieni pociagiem przez polową żandarmerię w kierunku Baranowa i 8 września 1939 roku - rozstrzelani. Niemcy szybko ustalili miejsce ich stracenia. Zwłoki odkopali i przewieźli do Nowego Sącza. 13 listopada 1939 roku na cmentarzu ewangelickim w Nowym Saczu (przy obecnej ulicy Orkana) odbył się ich uroczysty pogrzeb, w którym uczestniczył sam szef Dystryktu dr Otto Wächter. To niecodzienne wydarzenie, które miejscową ludność napełniło groza, było pretekstem do ogłoszenia Nowego Sącza miastem karnym, co pociagnęlo za sobą stosowanie przez wszystkie lata wojny zaostrzonych represji i aktów zemsty, przygotowywanych częściowo przez V Kolumnę, która w latach swej działalności sporządziła i przekazała Gestapo listy osób angażujących się wybitnie w działalność patriotyczna, antyfaszystowska, społeczną i polityczną. Listy te, przygotowane przez ,życzliwych ludzi” dały Gestapo dokładną orientację, kogo należy zlikwidować jako tak zwany element w warunkach okupacyjnych niepożądany ${ }^{46}$.

Innym powodem, że Nowy Sącz tak bardzo w czasie wojny ucierpiał, było wejście dużej liczby osób niemieckiego pochodzenia do służb policyjno-porządkowych okupanta. Ludzie ci znali dobrze miasto i cały powiat i naprowadzali swych mocodawców na tropy osób czy nawet całych grup odznaczających się kiedyś bardziej dynamiczną polskością.

Trzecim powodem tego, że Nowy Sącz, a właściwie cała Sądecczyzna tak wiele wycierpiała, było położenie tego terenu na pograniczu ze Słowacja, z czym wiązał się przepływ przez tę ziemię wielotysięcznej masy ludzi uciekających z kraju przed zemstą wroga, czy też chcących dostać się do armii generała Władysława Sikorskiego. Cała ta akcja, ten wychodźczy exodus oparty był głównie na pomocy mieszkańców miasta i okolicy, co najczęściej kończyło się aresztowaniem, obozem czy placem egzekucji.

Z przerzutów uchodźców przez granicę wyrósł drugi, obok organizacji, bardzo istotny element sądeckiego ruchu oporu - kurierstwo, zwane inaczej łącznością zagraniczną. Cała grupa sądeckich kurierów zaczynała jako przewodnicy

${ }^{46}$ Zob. J. B i e n i e k, A wasze imię: wierni Sqqdeczanie. Przewodnik po miejscach zwiqzanych z ruchem oporu antyfaszystowskiego w Nowym Sqczu i okolicy, Nowy Sącz 1986, s. 5. 
„holujący” uchodźców przez zielone granice na trasie: Warszawa - Nowy Sącz Budapeszt. Poznawali przy okazji zdawanie poszczególnych partii uchodźców na polskich placówkach dyplomatycznych w Budapeszcie, by wreszcie zostać zaprzysiężonymi jako kurierzy i pełnić ciężką, odpowiedzialną i niebezpieczną służbę na linii Warszawa - Budapeszt, wiążąc władze podziemnego państwa z rządem i sztabem naczelnego wodza na wychodźctwie. Za ten rodzaj służby zarówno miasto jak i powiat zapłaciły życiem wielu osób z tytułu pomocy udzielanej kurierom, emisariuszom i łącznikom, wśród których znalazł się między innymi Jan Karski ${ }^{47}$.

I wreszcie czwarty powód tak nielitościwych cierpień całego miasta i regionu. Nowy Sącz w latach międzywojennych był siedzibą I Pułku Strzelców Podhalańskich. To tutaj mieszkała kadra oficerska i podoficerska tej wyborowej jednostki. Część z nich wróciła $z$ kampanii wrześniowej i ledwo okrzepła $\mathrm{z}$ frontowej poniewierki, zaczęła organizować komórki wojskowego podziemia, wprowadzając w jego szeregi bardzo patriotycznie ukierunkowane społeczeństwo miasta i powiatu. Zaczęły rosnąc podziemne szeregi. Niestety, nie przestrzegano elementarnych zasad konspiracyjnego kamuflażu, co bardzo ułatwiło Gestapo zorientowanie się w sytuacji i podjęcie kontrakcji przy pomocy agentów i konfidentów, którzy docierając do tych miejsc - byli przyczyną częstych „wsyp”, których każdorazowym wynikiem było po kilkadziesiąt osób z samej czołówki organizacji. Reszty dopełniły nieszczęśliwe przypadki, jak gadulstwo, pijaństwo czy ujawnienie wymuszone na aresztowanych w toku śledztwa.

Nowy Sącz, jako stolica powiatu, miejsce postoju I Pułku Strzelców Podhalańskich oraz siedziba zarządów i komend wszystkich dzialających na Sądecczyźnie instytucji i organizacji, miał wszelkie dane, aby stać się bazą dyspozycyjną ruchu oporu. Na taką przecież był przewidywany i taką rolę faktycznie zaczął spełniać. Jednak niedługo. Już pierwsze wpadki dały podziemiu do zrozumienia, że w nasyconym gestapowską siatką mieście poważniejsza działalność jest niemożliwa. Stąd też większość ośrodków dyspozycyjnych podziemia kwaterowało w terenie, utrzymując w samym mieście jedynie najważniejsze ogniwa operacyjne, takie jak: wywiad, łączność, kolportaż, informacja czy propaganda.

W tym czasie na Sądecczyźnie istniały, prowadząc zaprogramowaną działalność, następujące organizacje: Służba Zwycięstwu Polski (SZP), Związek Walki Zbrojnej - Armia Krajowa (ZWZ - AK), Organizacja Orła Białego (OOB), Zwiazek Czynu Zbrojnego ( $\mathrm{ZCZ}$ ), Polska Organizacja Zbrojna (POZ) organizacja podziemna straży pożarnych kryptonim „Skała”, Polski Związek Wolności (PZW) i współpracujące $z$ wojskowym podziemiem harcerstwo. Na uwagę zasługują też: Polska Partia Socjalistyczna, nosząca w konspiracji nazwę „Wolność - Równość Niepodległość" (WRN) i jej przybudówka wojskowa znana jako Gwardia Ludowa, Stronnictwo Ludowe kryptonim „Roch" ze swym zbrojnym ramieniem Chłopską Strażą („Chłostra”), podzieloną w 1942 roku na Bataliony Chłopskie (BCh) i Ludową Straż Bezpieczeństwa (LSB) wraz z agendami cywilnymi: Ludowym Związkiem Kobiet (LZK) i młodzieżową kontynuacją przedwojennych „Wici”, używajacą nazwy „Młody Las”. Natomiast Polska Partia Robotnicza (PPR), mimo prób, nie zdołała utworzyć na sądeckim terenie mocniejszych przyczółków ${ }^{48}$.

\footnotetext{
47 Tamże, s. 6.

${ }^{48}$ Tamże s. 7.
} 
Po przedstawieniu, przynajmniej w ogólnym zarysie, przyczyn, dlaczego Nowy Sącz i Ziemia Sądecka tak bardzo wiele wycierpiały od okupanta, należy skupić uwagę na tym istotnym problemie, co było przyczyną aresztowań i śmierci tak licznej grupy ludzi, w tym ks. Józefa Bardla? Nie ulega watpliwości, że jedną z przyczyn był niemiecki odwet za wspomniane wcześniej aresztowanie jedenastu członków V Kolumny i ich rozstrzelanie pod Baranowem. Ta jakby główna przyczyna aresztowań i śmierci przewija się w licznych dokumentach poświęconych tej właśnie sprawie. Ale nie tylko. Historycy są zgodni w przedstawianiu i takiej przyczyny: swawolnego zachowania się warszawskiego studenta, który źle się czuł w swoim mieście i przybył do Nowego Sacza. Zbierał nawet ofiary, nie wiadomo z czyjego rozkazu, rzekomo dla potrzebujących ludzi. Studenta tego o nazwisku Daniłowicz, który budził podejrzenie, pod koniec czerwca 1941 roku ujęło Gestapo. Został on doprowadzony na posterunek Polskiej Policji Granatowej w dzielnicy Helena, przy ulicy Krakowskiej w Nowym Sączu. Zanim przystapiono do przesłuchania, niewiele się zastanawiając Daniłowicz wyciagnąl broń i zranił gestapowca Wagnera oraz policjanta Stanaszka, a śmiertelnie zranił trzeciego komendanta posterunku Jana Perlińskiego i zbiegł. Ukrywal się w Rożnowie u siostry, żony inżyniera Wasilewskiego oraz u doktora Stefana Durkota, u którego nocował. Już na drugi dzień studenta odnaleziono i osadzono w więzieniu, a następnie wywieziono do Oświęcimia, gdzie zginął.

To właśnie wydarzenie miało służyć jako pretekst do ujęcia wielu przedstawicieli sądeckiej inteligencji i być bezpośrednią przyczyną ich śmierci. Wątpliwe jednak, aby był to rzeczywisty powód.

Inną możliwą przyczyną aresztowań mogło być ujęcie w celu przesłuchania ucznia sądeckiej szkoły ekonomicznej Jurkowskiego. Podczas przesłuchiwania bito go i torturowano, w wyniku czego wymienił nazwiska ludzi, których rzekomo widzial przy różnych akcjach, takich jak na przykład kolportaż prasy. Ludzi tych 40 lub 50 osób - aresztowano. Był wśród nich prof. dr Jan Słowikowski - lekarz sądeckiego szpitala. Nastapiły przesłuchania. Kiedy - po licznych torturach aresztowanym niczego nie udowodniono, wypuszczono ich.

Jednak chyba najbardziej wiarygodną przyczyną aresztowania i śmierci tych ludzi była tak zwana „Akcja - Szpital”, która jako główne zadanie miała zorganizowanie uwolnienia $\mathrm{z}$ rąk niemieckich emisariusza rządu londyńskiego Jana Karskiego, nad czym w swoim liście pisanym niedługo przed śmiercią Jan Karski bardzo ubolewa ${ }^{49}$.

Wśród tych różnych przyczyn rozstrzeliwań, a wcześniej - aresztowań, trudno wskazać tę mającą bezpośredni związek z ks. Józefem Bardlem. Wiadomo, że założeniem wroga było zniszczyć inteligencję nie tylko Nowego Sacza, ale i innych polskich miast i wsi. Wiadomo również, że ks. Bardel, w wieku 57 lat, został najpierw aresztowany, a następnie - bez żadnego przesłuchania - rozstrzelany. Wlasne wnioski na temat stracenia ks. Józefa Bardla ma wspomniany już ks. Stanisław Pieprznik:

„Aresztowany 2 lipca 1941 roku i osadzony w więzieniu w Nowym Sączu ks. Józef Bardel został 21 sierpnia 1941 roku rozstrzelany w Biegonicach k. Nowego Sącza, wraz z ks. Władysławem Deszczem i ks. Tadeuszem Kaczmarczy-

${ }^{49}$ Zob. „Rocznik Sądecki” t. XXIX, 2001, s. 370-372. 
kiem oraz 41 osobami inteligencji nowosądeckiej. Gestapo miało go na oku, ponieważ parafianka Zawiślakówna chciała wyjść za mąż za volksdeutscha. Przyszła na plebanię po metrykę. Ks. Bardel zdecydowanie jej odmówił. Oskarżyła go na Gestapo. Księdza wezwano, który wytlumaczył, że dziewczyna ma skończone dopiero 19 lat, a prawo polskie wymaga 21 lat do pełnoletności. Zapewnil, że jeżeli dziewczyna przyjdzie z matką lub ojcem, metrykę otrzyma. I rzeczywiście, Zawiślakówna udała się na plebanię z ojcem i metrykę otrzymała.

Drugi przypadek miał miejsce $z$ innym parafianinem z Niskowej, Karolem Haglem. I on przyszedł do kacelarii po metrykę i zapisywał się na volksdeutscha. Proboszcz mu to zdecydowanie odradzał. I on oskarżył go na Gestapo. Księdza wezwano również i w tym przypadku. Jak się tłumaczył, nie wiadomo.

I jeszcze jedna sprawa. Jakiś młodzieniec pożyczył w Nowym Sączu, w wypożyczalni u pana Kądziołki rower, którym rozwoził gazetę podziemną «Polska zbrojna». Wpadł przy tym i aresztowało go Gestapo. Bito go w niemiłosierny sposób i miał wydać tych, którym gazetę dostarczał. Aresztowany był też pan Kądziołka, który mu rower pożyczył. Ten jednak tłumaczył się, że ma wypożyczalnię i wolno mu wypożyczać i nie ma obowiązku pytać, w jakim celu. Gazetę tę miał otrzymywać ks. Józef Bardel”, ${ }^{, 50}$.

Przytoczone powyżej przypadki w dość przekonywający sposób mogą wyjaśniać przyczyny aresztowania i stracenia ks. Bardla. Nie sposób jednak w przekonywający sposób stwierdzić, że zaważyła tutaj choćby jedna z nich. Należałoby zatem przyjąć hipotezę, że wszystkie przytoczone powyżej przyczyny aresztowań i straceń w jakiś sposób mogły się przyczynić do aresztowania i męczeńskiej śmieci trzetrzewińskiego proboszcza - ks. Józefa Bardla ${ }^{51}$.

W tym miejscu warto dodać, że ks. Józef Bardel podczas aresztowania nie był przesłuchiwany, mimo iż doznał wielu przykrości: był bity, kopany, szczuto go psami. Znosił to jednak ofiarnie. Wraz z dwoma innymi aresztowanymı kapłanami podnosił współwięźniów na duchu, prowadził rozmowy, dużo się modlił i spowiadał, szczególnie w przeddzień egzekucji. Tak kochał swoją parafię i rolę, że prosił, aby go podnieść na więzienny parapet, chcial bowiem zobaczyć, jak rośnie jego pszenica w pobliskiej Trzetrzewinie.

Wszystkich rozstrzelanych umieszczono we wspólnej mogile w Biegonicach. Wiosną 1945 roku odbyła się ekshumacja zamordowanych i wiele zwłok rozpoznano. Wszystkich pochowano we wspólnym grobie przy Alei Wolności na Starym Cmentarzu w Nowym Sączu. Ks. Józefa Bardla natomiast - wyjątkowo - o co zatroszczył się ks. Stanisław Pieprznik wraz z parafianami, pochowano na starym cmentarzu w Trzetrzewinie. Na jego grobie został umieszony pomnik przedstawiający ks. Józefa wraz z hitlerowskimi oprawcami i napis: „Tu spoczywa pierwszy proboszcz z Irzetrzewiny".

${ }^{50}$ Relacja pochodzi $\mathrm{z}$ archiwum autora.

${ }^{51}$ Tezy ks. Stanisława Pieprznika mają swoje potwierdzenie w nielicznych publikacjach na temat ks. Józefa Bardla, gdzie znajdują się m.in. takie zdania: „W czasie okupacji niemieckiej przeciwstawiał się przesadnej uległości niektórych parafian wobec okupantów, w czym naraził się okupacyjnym władzom. Skoro więc sądeckie Gestapo zaczęło stosować systematyczny terror względem ludności polskiej, uwięziło i tego kapłana o zdecydowanym charakterze kapłańskim i narodowym, i straciło go przez rozstrzelanie" (zob. A. Nowa k, dz. cyt,, s. 38, a także J. C i e r n i a k, R. M a z u r, Wspominamy, „Currenda” Tarnów 1947). 